\title{
Love Is the Cause of Human Evolution
}

\author{
Enrique Burunat ${ }^{1,2}$ \\ ${ }^{1}$ Department of Psychobiology, School of Psychology, University of La Laguna, Tenerife, Spain \\ ${ }^{2}$ Neurochemistry and Neuroimaging Laboratory, School of Medicine, University of La Laguna, Tenerife, Spain \\ Email: eburunat@ull.es
}

Received 1 January 2014; revised 2 February 2014; accepted 28 February 2014

Copyright (C) 2014 by author and Scientific Research Publishing Inc.

This work is licensed under the Creative Commons Attribution International License (CC BY). http://creativecommons.org/licenses/by/4.0/

(c) (i) Open Access

\begin{abstract}
Ever since the publication of "The Origin of Species by Means of Natural Selection" by Charles Darwin in 1859, many theories have been put forward regarding the reasons as to why animals and humans are different. Whilst there was an initial tendency to focus on the differences apparent in the main anatomic characteristics of the human body, in more recent time research has concentrated on differences that are evident both in the anatomy and in that of the workings of the human brain. While in the past, the essence of the human being was placed on the pelvic structure, the creation of tools or even the intermaxillary bone, the introduction of new technology and cerebral imaging is enabling us to glean previously unthinkable information regarding the evolution of specific structures and parts of the brain. All these discoveries can be associated with new theories based on a better understanding of the workings of the human mind. Hence, as a result of an enormous joint effort, a comprehensible description of the cause of the origin of mankind is emerging. This allows "love", once considered as merely a simple emotion, to be at the very core of explaining the evolutionary characteristics of the human being.
\end{abstract}

\section{Keywords}

Love, Human Evolution, Human Origin, Human Phylogeny, Human Ontogeny

\section{Introduction: Love and Evolution}

Love between people is usually considered in the psychological field as an emotion (Toivonen et al., 2012) or feeling associated with sexuality and impacting other mental functions, such as perception, even taste (Chan et al., 2013), or even stronger impact on health (Perlman et al., 1971; Hart et al., 2007; Carey et al., 2014) or reasoning (Weber \& Lehman, 2005). Among the components of love, perhaps attachment (Ohoka et al., 2014), empathy (Ciaramelli et al., 2013), sexuality (Rosenberg et al., 2014) and altruism (Ebstein et al., 2010), are those best known.

The emotional intensity and diversity associated with different stages of love contributes to the difficulty of pigeonholing love as a specific mental function. As a consequence of this, the precise location of love within 
mental functions is still unclear, although many recent scientific studies are clarifying its behavioral (Höglund et al., 2014), hormonal (Neumann, 2008), genetic (Schneiderman et al., 2013), or neuronal (Acevedo et al., 2012) components, and even its relationship with some other mental functions such as attention (Langeslaq et al., 2014) or memory (Alea \& Vick, 2010).

From an anthropological perspective, researches focused on love, sexuality and mating have shown their enormous diversity in different cultures (Mascie-Taylor \& Boyce, 2009). There are also recent proposals for feasibility and consequences of coupling between hominid species, for example between $H$. sapiens and $H$. neanderthalensis, based on matches between chimpanzee and bonobo (Overmann \& Coolidge, 2013).

Although some authors assume that love developed gradually throughout the evolutionary process, with some of its peculiarities apparent in extinct hominids (as compassion-Hublin, 2010), others limit the appearance of love only to recent times and only in our species, also assuming in many cases, that love is only an emotional component of sexual interest.

From an evolutionary viewpoint, some components of love seem to be present in several classes of vertebratesmaternal attachment shown in some reptiles, courtship and fidelity in many birds ..., suggesting its gradual formation through the process of natural selection, although perhaps homeotherms animals -birds and mammals-, are those showing the best evidence of such components (Fisher et al., 1998, 2006; Fisher, 2004).

Several already known phenotypic characteristics of human beings are presented in this article. Although they have been explained separately, mostly in anthropological terms, when interpreted together they suggest that love is a specific feature of evolutionary phylogeny of hominids.

At the same time, such evidence is consistent with recent findings about the brain substrate of love, allowing a joint interpretation of conclusions from neuroscience and anthropology which seems reasonable in the overall picture of biological evolution. In this interpretation, love is the crucial factor responsible for human ontogeny and phylogeny.

\section{Love Caused Human Evolution. Some of the Reasons}

The list of points to back this argument is not only extensive but indeed overwhelming. Any one of the motives found and imagined to explain the peculiarities or discoveries related to human evolution could easily refer to love. The following sections show some of these and it should be understood that they are quoted not as anecdotes regarding the workings of the human mind but as the result of the positive selection of such aspects throughout the evolution process and therefore subject to the mechanisms of natural selection. All these motives, caused by or associated with love, have a repercussion in the development of Mankind by increasing the biological efficiency - fitness of the human race (and probably that of other human species).

\subsection{Childhood}

The first is the appearance of childhood in the evolution of hominids (Rozzi \& Bermúdez, 2004). This can only be explained by the existence of maternal love. If not who else would feed, carry, look after and protect its young? Of course it's the mother and the motive is human maternal love. It is a love that is new to nature with a different cerebral and genetic make up to, say, that of the mother crocodile (Crocodylus moreletii) or certain cichlids (Cichlidae) at sea who carry their young by mouth from one place to another to protect them from predators. A very different type of love to that which leads certain ungulates or birds to ostensibly hobble about in front of lions and other predators in order to lure them away from their young hidden in the long grass. Contrary to the presumption that humans have low fecundity and an inefficient reproductive system, which has been challenged by Vitzthum (2009), love is the main cause of evolutionary success of our species through increasing the fitness of human populations.

A love that is not wholly determined genetically but by a huge behavioral flexibility thanks to the great anatomically modern Homo sapiens (AMHS) brain, which has populated the earth in the last one to two million years (Pearce et al., 2013). Recent data from the Spanish site of Atapuerca show evidence of the existence of a prolonged childhood in Homo antecessor, similar to the present, about 900,000 years ago, long before the emergence of our species (Bermúdez de Castro et al., 2010).

\subsection{Weaning}

Human babies are weaned before any other existing large primate (Smith et al., 2013), continuing a tendency 
observed in other extinct hominids (Smith et al., 2010). The care of their still defenseless young, and their laborious feeding once weaned, could only be motivated by maternal love, rather than by the implementation of social brains and the structure of group organizations which our predecessors could have had. Moreover, it is more likely that such family and social structures were, and are, derived from the creation of love, for the benefit of the evolutionary process, in the line of human evolution.

\subsection{Nakedness}

The hairless, bare skin obliges the human mother to permanently carry her baby and it has been suggested that this is an essential factor in humanization (Sutou, 2012). Such a bare skin, so new in nature to primates that baby humans still retain the grip reflex which enables them to cling to their mother while she is doing other things. This occurs not only among primates; for example, also the breeding of the giant anteater (Myrmecophaga tridáctila) clings firmly to the back of his mother when she moves.

In order to understand the ability of carrying out such a demanding and absorbing job as that of rearing the young, not only do we always come back to maternal love, but also, as will later be commented upon, it could be one of the pillars in the formation of the human mind, developed when the brain was designed to control the attention span to an extreme and almost permanent level. To that end, the implementation of love must have been essential, and perhaps this is how the thread of human thought began to unravel.

\subsection{Caressing}

The caressing, present in mother-child and sexual relationships, is possibly due to very sensitive sensorial receptors in the palm of the hands and in the fingers which permit us to express love. The de-parasiting of the body hair is a social process apparent in most primates bringing about a new erotic function, associated with the creation of love between adults, transmitted through specific nerve fibers (Olausson et al., 2002).

Faced with the insistent ability to manipulate which brought about the opposable thumb, it is reasonable to assume that human hands have played a key role in the experience and communication of love, as a way of continuing their previous function of de-parasiting and handling. In this way, tickling could be associated with certain instigating practices in human communication and this is why tickling provokes distinctively human laughter characteristics, compared to that heard in other primates (Davila Ross et al., 2009).

During intimate maternal or sexual moments, verbal language almost disappears, substituted by a variety of guttural, babbling sounds, cooing sounds and groans, yet always accompanied by caresses. If individual language acquisition is in some way connected to mother-child genetics, then caresses must accompany the primitive systems of communication in humans, both verbally and non-verbally. Love should be the main driver of this communication system.

\subsection{Longevity}

Female longevity is superior to that of the male in every society (Wingard, 1982; WHO, 2013, Seifarth, 2012). Its physiological reasons, mainly hormonal, are already known, and the longevity of Korean eunuchs, promoted by male hormones depletion, has been confirmed in a recent publication (Min et al., 2012). However, the evolutionary reason for the different life-expectancy between a man and a woman is less known as it doesn't seem to occur in other similar species, such as chimpanzees where the female dies shortly after reaching menopause, both in wild life (Emery-Thompson et al., 2007) and in captivity (Herndon et al., 2012).

If love is created and maintained by brain activity particular to human mothers, this maintenance assures the survival of her children, through infancy, childhood and adolescence. The mothers who died prematurely weren't able to ensure the survival of their genes in their children and grandchildren, so the longer they were alive, the more their longevity genes were passed on.

The discussion regarding the relative importance of the role of the mother as opposed to that of the grandmother is still continuing (Hawkes \& Smith, 2009; Madrigal \& Melendez-Obando, 2008) but loses importance when contemplating the creation of maternal love as being the cause of female longevity. This is of enormous technical interest also for the understanding of human family organization, sexual selection, and human fitness, in its initial phases (Moorad, 2013), and even to understand human longevity in both sexes (Hawkes \& Coxworth, 2013, for an extensive overview, see Crews, 2003). 
Thus, the implementation of love can be directly associated with the selection of genes responsible for female longevity, for the survival of women long after the menopause and, by extension, it may be considered mainly responsible for human longevity.

\subsection{Sexual Dimorphism}

While in the general population there are little differences in body size between men and women, some important parameters do not show any difference, for example, the width-height ratio of the head in some groups (Kramer et al., 2012). A phylogenetic reconstruction of the evolution of dimorphism, including fossil hominines, indicates that the modern human condition, and characteristics associated with dimorphism, may have arisen independently and not directly from a common ancestor with chimpanzees (Playcan, 2012).

In the human species sexes have evident sexual characteristics, the male has the largest penis in erection of all existing primates and women have the largest mammary glands of all female primates (for a comprehensive review of human sexuality under an evolutionary light, see Gray, 2013).

With regard to the penis, it is evident that natural selection has brought this about for its repercussion on reproduction (i.e., during copulation). Indeed, its importance has been explained for the vaginal orgasm (Costa et al., 2012), and also, it has been recently shown that female mate choice could have driven the evolution of larger penises in humans (Mautz et al., 2013). Therefore, a large erect penis does not constitute evidence that sexuality has directed the recent human evolution. On the contrary, it is a support for the idea that a larger erect penis is only an instrument dedicated to enhance the pleasure of women (Costa \& Brody, 2007), and thus to increase the addictiveness of love in both sexes.

As for the mammary glands, despite the possible argument that a more prominent bust is more effective in attracting a male these days (Gueguen, 2007), which is now part of present day culture, it appears evident that natural selection brought about this development for its repercussion on the survival of descendants, that is, for breast-feeding. But, possibly large breasts were also useful to maintain male sexual interest during child rearing (which in turn, produced better survival rates for women, their children and for the genes of both parents). In any case, it doesn't appear to be only sexuality, merely sex present in all species, but rather the creation of human love, which is responsible for such particular sexual characteristics of men and women.

\subsection{Genitals}

Male genitalia have been previously treated; although a large erect penis is a peculiarity of our species between great apes, men testes do not have special features between modern great apes.

With respect to the female, the woman's external genitals are hidden, almost imperceptible, both in the biped and quadruped position (Tosevski \& Tosevski, 2006). This is a very noteworthy characteristic, in fact unique amongst the female primates, many of whom produce a swelling of the rump when on heat, acting as a visible signal of their reproductive phase. Given that natural selection has clearly acted in the negative selection leading to the practical elimination of the female external genitals, this appears to be sufficient reason to believe that sex has not been the driving force for recent human evolution.

A negative selection regarding the sexual signals may be considered infrequent in biological evolution. In fact, sexual selection, already stated by Darwin (1871) and nowadays by other authors (Miller, 2007) is a key mechanism in the evolution process even now (Courtiol et al., 2012), for example, in the diversification of the immune system (Winternitz et al., 2013).

It is at this point that the significance of the creation of love becomes apparent in the evolutionary line of human being, differentiating it from sexuality.

\subsection{Sexuality}

Women are always sexually receptive but don't show any physical signs of their reproductive state, except during menstruation, although their sexual interest is certainly influenced by hypophisiary and gonadal hormones (Guillermo et al., 2010). Such a situation is equally surprising in the Mammalian biology given that when the female is "on heat" and of reproductive interest, this corresponds to the days of ovulation, thus ensuring pregnancy and the consequent success of the evolution of the species (of course, there are several exceptions, such as in rabbits or bonobos-Pan paniscus). 
Once again, this fact can be interpreted as an example of the subordination of sexuality towards love during human evolution. In this way, there emerges an integration of sexual activity within the new mental function of love, created by natural selection to accompany the peculiarities described in previous paragraphs, all of them being, including sexual behavior, subordinate to the survival of the young.

Sex is the strongest drive in animal behavior, and by allowing frequent sexual intercourse between the parents, natural selection ensured the stability of the couple throughout the child-rearing years and by the same measure the survival of the children. In this way, when analyzed, frequency of penile-vaginal intercourse correlated positively with Satisfaction, Intimacy, Trust, Passion, and Love in the Global Relationship Quality Inventory. However, non-coital sexual behaviors were uncorrelated with those dimensions, and even masturbation frequency was inversely associated with Love (Costa \& Brody, 2007). Thus, although sexual pleasure and love are different motivations, they combine synergistically to promote family stability and survival of their offspring.

\subsection{Fidelity}

The stability of sexual human partners is maintained by fidelity, one of the key components of love. Whilst the majority of birds are monogamous, amongst mammals, promiscuity is the norm (Fisher et al., 1998, 2006), thus biological evolution resolved the problem of defenseless human children, selecting the creation of maternal love and extending that same function to that of the relationship between the parents.

The neuronal substrate of fidelity in some species of mammals is already known, such as in the field mouse (Microtus ochrogaster), which are found in certain receptors in the nerve cell membrane of the nucleus accumbens (Aragona et al., 2003, 2006). However, for the establishment of fidelity in humans, natural selection chose the procedure of creating a potent addictive process towards certain physical and mental signs in the couple, encapsulated in the creation of love whose cerebral substrate is also known in detail (Bartels \& Zeki, 2000, 2004; Fisher et al., 2002).

Fidelity is associated to the main circuit of cerebral reward and allows great flexibility, given that it doesn't arise from the commitment proposed by some psychological theories on love (Sternberg, 2004), but by the result of an addictive process created by natural selection to ensure biological fitness in the human species accompanied by its success in reproduction.

The faithful parents, lovers of their partner and their offspring, transmitted their appropriate love genes, unlike the selfish parents who disowned their children, then these dying. Humanfidelity arises in women, in the maternal relationship and, according to a recent simulation exercise, fidelity must have extended rapidly as a characteristic of most males with the exception of high ranking males (Gavrilet, 2012).

\subsection{Birth}

The pain caused by the deflowering and rupture of the hymen, and giving birth, constitutes some characteristics which are seldom considered in human evolution. It has been suggested that it implies the need for a strong motivation on the part of the woman to have sexual intercourse for the first time (Maul, 2007), and so it could be associated with the creation of human love, which among its addictive characteristics, implies the capacity to overcome the physical and emotional barrier imposed by the hymen.

The relationship between pain and emotion is known (Stancak \& Fallon, 2013), as well as its relation with empathy (Singer et al., 2004). The pain usually associated with the rupture of the hymen, in the same way as that which usually accompanies the hardship effort required to give birth, can only have been selected positively by the natural selection process if these experiences were necessary to strengthen the establishment of an intense emotional relationship between partners (Maul, 2007). The explanation appears obvious in the context of the creation of human love, which causes and stimulates the most intense emotions which a person can experience.

Not that love arose after the occurrence of difficult deliveries, but rather the pre-existing love allowed the survival of mother and baby when new species developed an increasingly difficult birth.

\subsection{Reproduction}

The high reproductive level of the human species is without comparison among the large existing primates. However, it must be noted that human gestation is absolutely longer (38 - 40 weeks) than that of chimpanzee (Pan, 32 wk), Gorilla and Pongo (37 - 38 wk), and indeed, the data indicate that gestation has increased in the 
hominid lineage (Dunsworth et al., 2012). But all the previous factors combined allow a woman to have a child every year or two, reproducing at an unachievable frequency in other great apes (chimpanzee and gorilla, 4 to 6 years, orangutan, 7 or 8). The rapid termination of the breast feeding period and subsequent pregnancies must have required paternal collaboration, given that the genes of the selfish fathers, who didn't help their partners, must have disappeared quickly along with their offspring, according to what has been suggested (Gavrilet, 2012). The importance of the help of other females, previously touched on in point 5 , is a factor which also can explain the gene selection responsible for female longevity, mainly having in mind feeding limitations.

It has been recently proposed that the power supply (and not the pelvic diameter) was the limiting factor of the increase in brain development in both pregnancy (Dunsworth et al., 2012) and human phylogeny (Fonseca \& Herculano, 2012). These points and others combined harmoniously to make family and group organization possible, and turned everything around food acquisition. Indeed, the creation of human love would become an essential factor in the building of what is known as the "social brain" to which many authors attribute the origin of mankind's peculiarities (Dunbar, 2012; Pearce et al., 2013). In short, the fitness in the species could not be greater considering the factors associated with the length of the gestation period.

\subsection{Addiction}

The addictive inclination present in humans is extraordinary. In the last few thousand years a host of substances have been cultivated, created and have become widespread, to which people can become addicted. There is also an enormous variety of manners and behaviors capable of creating addition. All these can be associated with the effect they have on cerebral structures whose relation to love is already known. It has also been recently explained that the unpleasant symptoms of abstinence which provoke the continuation of consumer habits such as substances like cocaine, can refer to a brain function similar to those produced by the breakdown of a love affair (Fisher et al., 2010).

Although at this given time it is not possible to generalize this discovery to include all existing addictive drugs and behaviors, it is a fact that the pleasure such drugs and behaviors can generate has a cerebral substrate in common with that generated by love (Bartels \& Zeki, 2004), mainly, the dopaminergic ventral tegmental area, as well as related areas, in long-lasting relationships (Acevedo et al., 2012).

Furthermore, recent research establishes the utility of the use of oxytocin, associated with attachment and love (Scheele et al., 2013), in the treatment of drug addiction (McGregor \& Bowen, 2012; Pedersen, 2014). However, it should be noted that not everyone believes in the addictive power of love (Reynaud et al., 2010) as it is beginning to be proven that the anatomy and brain chemistry of love and addiction are closely related.

Here, it is proposed that the human capacity to love can explain the apparent tendency to create and invent substances and methods capable of generating addiction, from drugs to Internet use (Romano et al., 2013), or mobile phone use (Kwon et al., 2013), which have already been proven to have an addictive quality. In humans the creation of love originates from the mother-child love, and the woman is the specific subject of the positive selection of fidelity, extending quickly at a later date to men. As in love, or when experiencing jealousy (Sagarin et al., 2012), addiction processes are different in males and females, as has been shown, for example, in nicotine dependence, where females show stronger functional coupling between brain structures involved (Wetherill et al., 2014), some of them also implied in love experience, as insula or anterior cingulate cortex.

Unlike the sexual pleasure that can be obtained with any other person, love is an addictive process specifically triggered by certain physical and mental characteristics of the beloved. In evolutionary terms, it makes no sense that a person can become addicted forever to alcohol or other drugs, and that instead he or she can fall in love several times in life, or that love only lasts a few years. Love is a mental function that can be put in the category of physiological motivations, such as hunger or thirst. Like these, it is composed of different behavioral components and internal states. All the different addictions perhaps only put in evidence spurious activations of brain circuits associated with love.

\subsection{Language}

The origin of language can easily be explained through the emergence of love in the mother-child relationship. Language evolution shows at least three essential characteristics which are briefly described in the following, together with its dependency on the creation of love. 


\subsubsection{The Beginning of Language}

Language acquisition requires exposure to the same at a point in a person's development which finishes at around puberty, this is especially important in learning a second language, and having different consequences in cortical thickness of temporal lobes, depending on the age of acquisition (Klein et al., 2013).

The initial sounds produced by the mother and baby helped strengthen, and were strengthened by, the experience of mother-child love in the evolutionary line of the hominid. The genetic determination of a language based on facial expressions, as suggested by Charles Darwin (1872) and which Paul Ekman has demonstrated, extends to all other existing human beings (Ekman, 2009). It should probably be extended to all other existing hominids of recent periods, given the probable emotional speech determination (Jablonka et al., 2012).

The cause of new vocal sounds added to facial expressions such as gurgles, whimpers and babblings have been motivated by pleasure, as pleasure accompanies communication as recently demonstrated (Tamir \& Mitchell, 2012), playing the part in a spiraling addiction in the mother-child communication, and being the main speech instigator.

Thus facial, guttural, body and finally verbal language arose from the boundless capacity to love, which was gradually established in the brain of the anatomically modern human species (AMHs).

\subsubsection{Language Dimorphism}

Language building in the human brain follows similar traits in everybody if the necessary conditions are available for its acquisition. The rhythm and sounds of the words that are acquired are especially notable in the first years of life, acquiring a large vocabulary with enormous speed (Goldfield \& Reznick, 1990), unachievable by other primates who have been trained with symbols or sign language for the deaf (Yang, 2013). This proves the peculiarity of the human brain for verbal language, although other cerebral adaptations related to communication in other primates are also known, for example, in the chimpanzee (Gannon et al., 1998), and even in other types of animals, such as birds (Moorman et al., 2012).

It is also known that the acquisition and mastering of language is superior in girls compared to boys (Erikson et al., 2012), which demonstrates the special preparation for communication of the female brain, as with its relation to the creation of maternal love.

Love, originated in the mother-child relationship, has the woman as its initial subject, with recognized differences to the male sex with regards to cerebral emotional experience (Koch et al., 2007), and language (Harasty et al., 1997).

Thus, language was instigated by natural selection and began emerging in women, motivated by love.

\subsubsection{Language Genetics}

Language acquisition requires at least two types of genetic conditions, firstly, mutations related to cerebral connections which are becoming known (Lai et al., 2001; Enard, 2011), as are their functional consequences (Bowers et al., 2013), and secondly, mutations implicated in the necessary adaptation of the voice box to permit the phonetic sounds of our species and which are not found in other primates. This was achieved mainly by shortening of the face, as recently shown in the Zuttiyeh fossil, between 500.000 and 200.000 years ago (Freidline et al., 2012). As it is unimaginable that both groups of mutations were produced simultaneously in the present human species, this should be interpreted as the human brain possessing the capacity to create language-as a result and motivated by love-in other now extinct species of hominids.

Thus, a brain capable of speaking must have existed before the mutations responsible for the shortening of the face, necessary for the supralaringeal and the oral cavity implicated in the voice box. In the same way, the human's ability to learn a language is proof of the role of natural selection and genes in this process. Although most of the FOXP2 gene is shared with Neanderthal, recent findings show genetic differences that may have had an impact on the language of modern human (Maricic et al., 2013).

Other authors have already expressed ideas in favor of the existence of brains capable of speech, although with less phonemes and more guttural sounds (Johansson, 2013), and perhaps language evolution started like the evolution of reading and writing, through cultural evolutionary processes, and with language enhancing the inhibitory control of emotions (Jablonka et al., 2012). This idea conjures up a picture of humans populating the Earth in the form of diverse species, in an authentic evolutionary explosion which created more than 20 species or forms of hominids (Tattersall \& Matternes, 2003), referred to as AMHs, throughout the last two million years. Before the existence of the voice box, love instigated facial, guttural, body and primitive verbal communication 
shared by other human species as can be seen in a nerve channel that controls the tongue muscles similar to the present day human at a little under 500,000 years ago (Kay et al., 1998).

It has been recently demonstrated how FOXP2 gene is more expressed in the left hemisphere cortex of 4year-old girls than in boys (Bowers et al., 2013). So, in those diverse species with the line of descent still unknown, love was selected positively judging by its repercussion in the survival of descendants and the consequent increase of biological fitness in the current human species, in part by promoting a more rapid and effective language acquisition in women.

\subsection{Phylogeny}

The creation of love throughout human phylogeny can be confirmed by studying the existing proofs related to some of the previous factors. In this way, it is not credible to believe that all the points that have been dealt with previously, and which characterize the present human species, will have emerged suddenly in one single couple and at one single point in the past. On the contrary, it is more likely to be found present in several of the other species that probably accompanied or preceded the current Homo sapiens, being perhaps their extinction promoted by the sole survivor (Bokma et al., 2012), and there are proofs that several of these factors were already evident in other AMH species: basic "modern" morphology seems to have appeared significantly earlier in time than the first stirrings of the modern symbolic cognitive system (Schwartz \& Tattersall, 2010).

So, to add some other examples, from the study of fossilized teeth, the evolutionary period of childhood in various species can be gradually reconstructed, showing a general trend to a shorter weaning and prolonged childhood, possible above all, by maternal love. Also, data originating from the analysis of the length of fingers -associated apparently with polyginy — there emerges a family organization in various previous hominid species, but not in others (Nelson et al., 2011).

So, the phylogeny of love should be understood as the gradual appearance of a new ability which defines the main peculiarity of the human evolutionary line, above all others that have been previously pointed out, such as the upright position, the building of tools, the making of fire or language.

Also, it was previously noted that in the human evolutionary line there is a noticeable tendency to similarity in body size between males and females, showing less sexual dimorphism than that existing between other large extant primates (Robson \& Wood, 2008). This fact cannot be explained through a predominant perspective which attributes some of the peculiarities shown in previous points through the notion of a purely sexual selection, otherwise it would, with all reason, have increased dimorphism, or at least would have maintained different body sizes, as in other species of great apes.

The cause of human sexual little size dimorphism is uncertain (Playcan, 2012), but the gradual building of love through female selection could be a key factor, affecting both simultaneously, the mind and the human body, rather than other factors commonly considered, such as mate competition, resource competition or intergroup violence.

It would appear that the creation of the phylogeny of love has altered the course of the mechanism of sexual selection towards the invention of love, recovering and integrating some previous abilities, such as fidelity, empathy, pleasure etc., and adding others, perhaps in a similar way to which evolution created flight in insects and later invented it in birds (feathers, hollow bones, muscles...). Today it seems obvious that love must be understood as a physiological motivation (Fisher, 2004; Aron et al., 2005; Xu et al., 2011), like hunger, thirst or sleep and not as a simple emotion in which it is pigeon-holed.

Finally, love may be the only reason explaining the survival of some fossils, as the Homo erectus 1.5 million years ago, recently discovered by a Zurich team. Following the authors of this paper, the fossil shows such damage to his spine that only advanced social care could prevent death several months before production (Haeusler et al., 2013). Presumably, maternal love should be the responsible for the amazing survival of this and other fossils, as the Neanderthal partial skeleton of La Chapelle-aux-Saints I, (Trinkaus, 1985), or the child with a skull deformity over 500,000 years ago discovered in Atapuerca (Gracia et al., 2009).

In these, and similar cases, instead of compassion (Hublin, 2009), or in addition to, love was probably essential for the organization and for the survival of individuals in human groups.

\subsection{Ontogeny}

Love is an essential factor in human ontogeny. The individual development of the human being requires the ex- 
perience of love, in the same way as the development of the visual system and visual cortex needs the experience of light (Espinosa \& Stryker, 2012), or as in the case of the stimulation of the sense of smell that causes the production of new neurons in all components of the brain circuit implied in the sense of smell (Shapiro et al., 2009). In the same way, mental functions have been associated with brain development (Casey et al., 2003).

Data obtained from the clinic show the importance of the experience of love in the construction of the human brain and mind. Thus, the lack of love, understood as abandon, violence or sexual abuse in infancy or childhood are the origins of disruptions in the workings of the adult brain (Bremmer et al., 1999, 2003; Márquez et al., 2013), and with different repercussions in both sexes (Edmiston et al., 2011), which is worth stressing due to the special sensitivity towards love of the developing female brain due to reasons of previously stated phylogenetic traits.

After childhood, the developing adolescent brain remains equally affected by the exposure of abusive drugs and by sexual abuse (Kolb \& Whishaw, 1998; Mathew et al., 2004). The risk factors associated with involvement in youth crime tend to be the same in different countries (Sampson \& Winström, 2008). Whilst an earlier study has noted that poverty and social problems in the childhood family have long-term consequences for the risk of exclusion much later in life (Bäckman \& Nilsson, 2011), a recent study on three different cohorts illustrates stability concerning the long-term consequences on inequalities in childhood conditions and involvement in crime, and also concerning the inability of society to satisfactory deal with these problems over time (Bäckman et al., 2014).

Given that love and reward circuits are closely related, perhaps this is the route by which violence and pain can produce pleasure in certain individuals (Porges \& Decety, 2013). Maltreatment in infancy doesn't only affect the individual, but in the case of girl victims can also have repercussions on her offspring. By way of this, changes in levels of cortisol production during pregnancy have been found in women who were victims of child abuse (Bublitz \& Storud, 2012), which is now known to alter the ulterior brain development (Singh et al., 2012).

Furthermore, data from criminology studies and psychologists also show that the infancy and childhood of some serial murderers was marked by a lack of love (Mitchell \& Aamodt, 2005; Vronsky, 2004).

It is left to conclude, in the light of these discoveries, that love in the first stages of life drastically influences the configuration of the developing brain. Although we are starting to know some of these genes (Márquez et al., 2013) and cerebral structures (Mathew et al., 2004; Edmiston et al. 2011; Márquez et al., 2013) implied in such consequences, it is of no less importance to recognize the fact that the lack of love during the formation of the human brain can affect subsequent generations, and also other people than those directly affected.

Finally, if love is a crucial factor in human ontogeny, this argument can be used as indirect evidence (as proposed by embryologist Ernst Haeckel) supporting that love has played an important role in human phylogeny.

\subsection{Brain}

The substrate of love involves several cortical and subcortical structures from various functional systems, e.g., the mesolimbic reward circuit already mentioned and which is involved in its addictive character, but also others, such as the mirror neuron system, and the mentalizing system. All of them can easily be associated with love

The creation of love in human evolution must have been associated with cerebral circuits responsible for empathy, which is more extensive in humans and consists of larger brain areas than in other existing primates (Sale \& Franceschini, 2012). Mirror neurons, originally discovered in the premotor (Gallese et al., 1996, 2004) and parietal (Gallese et al., 2002) cortex of monkeys, are a class of neurons that discharge not only when individuals perform a particular action but also when they observe or hear others performing the same action.

Neuroimaging and neurophysiological investigations show evidence of the existence of a cortical network with the properties of mirror neurons in humans: the mirror neuron system, that seems to include the premotor cortex, the caudal part of the inferior frontal gyrus and the rostral part of the parietal lobe and which is involved in understanding the actions of others and their intentions (Modroño, 2012). Other structures, such as the insula and the anterior mesial cortex, are activated by emotional stimuli (Singer et al., 2004), then associating the mirror neuron system with love.

It is known that watching social interactions produces dorsomedial prefrontal and medial parietal function increases (Iacoboni et al., 2004), and so, human frontal brain development could be stimulated by scrutiny in the mother-child interactions (in both, ontogeny and phylogeny, and motivated by love), rather than by the observation of complex interactions between adults. Furthermore, it is also of interest the finding that action perception 
can lead to both augmentations and decreases in the activity of these brain regions (Modroño et al., 2013). The use of such circuits to understand the minds of others must have constituted an indispensable mental tool in the mother-child and social relationships, and its defects are now associated with disruptions of the human mind as those present in what is known as the autistic spectrum (Wong et al., 2012; Wan et al., 2010).

Mentalizing, also known as the theory of mind (ToM) refers to the ability that enables one person to build a model of another's mind to infer intentions, goals and desires. ToM research has led to the anatomical definition of the mentalizing system, which consists of the precuneus, the temporoparietal junction and the medial prefrontal cortex (Modroño, 2012).

Recent neuroimaging studies in humans have indicated that individual differences in social network size correlate with amygdala volume and the volume of brain regions associated with theory of mind in both human and monkeys, and these findings provide crucial support for the social brain hypothesis (Dunbar, 2012). Thus, socially excluded individuals show defects in prefrontal development (Powers et al., 2011). Recent work from our laboratory has also found that the nature of the opponent also affects emotional and attentional processes. So, it has been found a parallelism between mentalizing and sympathetic nervous systems activity patterns that is related to emotional arousal (Modroño et al., submitted). Given that love is recognized as the cause of the most intense emotions a person can experience, love must have accompanied, at least, if not caused, the evolution of both, the mentalizing system and the mirror neuron system.

Love builds upon a neural circuit for emotions and pleasure, and it is obviously associated with sex, as described in a recent meta-analysis of brain activity in both functions (Cacioppo et al., 2012), but love is also associated with breathing, pulse, vision, memories, and many other brain functions, and cannot be reduced to them. In fact, in the female brain, the intensity of love experienced is mediated by the angular gyrus, whilst a different structure, the insula is associated with orgasm (Ortique, 2007); furthermore, in this work, no relationship was found between intensity of love and partnered orgasm frequency, presumably because sex is not the more important factor for the emergence of love.

The cerebral substrate of love implies a variety of structures which respond in different ways in different stages within a love relationship. Among them being the frontal lobes, and specifically, the prefrontal cortex and several subcortical structures, such as the Islands of Calleja, which have been suggested as allowing the integration of sexuality into the superior functions in the cerebral cortex (Stevens, 2002). Islands of Calleja complexes are present in all species and attain maximum development and dispersion in humans (Meyer et al., 1989).

Malfunction of these and other love-related brain structures (among other fascinating works, see Fisher et al., 2010; Acevedo et al., 2012; Bartels \& Zeki, 2004; Aron et al., 2005; Ortigue et al., 2010; Cheng et al., 2010; Kim et al., 2009; Xu et al., 2011) have been associated with serious consequences in the functioning of the brain, with the beginnings of schizophrenia (Inta et al., 2010), obsessive/compulsive disorder (Harrison et al., 2009), the attention deficit and hyperactive disorder (Bauer et al., 2013) and others, such as akinetic mutism, psychosis and addictions. All of them can arise as a result of anomalies in love-related brain structures. From this viewpoint, love circuits are essential in the construction of the human mind, and so, love must be considered an epigenetic crucial factor for brain and human mind development.

\section{Conclusion}

This article proposes that love is a physiological motivation which emerged in the human evolutionary process and it is also responsible for the main features of humanity. Such features would not have been possible without the prior creation of love through the process of natural selection. So, it has been here shown, for example, that it is not that love can be expressed through language, but language is a consequence of the prior creation of love in the evolutionary line of hominids. Thus, the progressive development of the various types of intelligence (mathematical, emotional, verbal...), mostly associated with language, and even consciousness, can also be considered the result of the previous construction of love.

Furthermore other factors came about in the hominid evolution as a consequence of the establishment of love such as the manipulative ability of the hands, or the greater female longevity compared to that of the male, or the prolonged survival of women after menopause, or the presence and prolonged childhood in successive human species, or to the prominent human tendency to substance use and to creating procedures and skills triggering pleasure and dependence.

Evolution not only creates bodies and forms but also new abilities. The evolution of genes and bodies not only 
aim to create new abilities, such as the utilization of glucose or flight. Love is the capacity created through evolution in the human evolutionary line and it is responsible or affords an easy explanation of all human peculiarities which have previously been put forward as the cause of humanity.

Love is a physiological motivation (as hunger or thirst), non-existent before the hominid evolutionary line and some of its characteristics can be found in other evolutionary lines with a clear genetic determination. Such an example exists in fidelity and monogamy, mainly present in birds and with a strict genetic program.

Despite the existing proofs, it won't be an easy task to achieve a general acceptance of the idea that the creation of love is the essential factor in the evolution of hominids and the unique factor that explains the main peculiarities of the present human species. The acceptance of the relevance of love in human evolution implies an essential change which may not be easy to assimilate in present day human societies, where love is considered merely a simple emotion accompanying sexual interest. On the contrary, natural selection, building the capacity to love in the human species, is responsible for all human phenotypic characteristics, as shown in the above, including language and human consciousness. Human species would not have arisen without the creation of love by natural selection.

The western culture (really, most cultures) measures success and happiness through the obtaining of power and material goods, which implies an evolutionary regression of maybe over a million years, before the beginning of the slow creation of love by natural selection in the human evolutionary line. Perhaps only dominant chauvinism in present day societies and also science, has ensured that the essential role of women and love in human evolution remain hidden, despite the abundant and significant evidence as resumed in this article, attributing more importance to other factors which demonstrate better male achievement, such as social group organization and the building of tools.

Even in religions which insist on the importance of love in their rites and scriptures, women are kept away from important posts. Those in power are responsible for the confusion between love and sexuality, by managing to control sexuality (marriages, divorces, abortion...), which is one of the main sources of power in the majority of animal species with social structure. Throughout history, the control to the access of sex, via the most diverse ways, has been the main means of controlling the population by political and religious groups, and science too has had a hand in such manipulation.

Although the amount of neurobiological, genetic, physiological, psychological and anthropological arguments are overwhelming, which prove the importance of love in human evolution, the brief summary described in this article has only permitted an outline of a line of argument which is expanded in greater detail in a book by the author, in Spanish (Burunat, 2014).

Many other authors and experts in various fields will be able to evaluate this proposal adequately and may extend and perhaps, confirm the main idea in this article: that love is not only an emotion accompanying sexuality but the very main physiological driving force responsible for the origin and the evolution of humanity.

\section{Acknowledgements}

The author thanks Mrs. Loraine Guy for her technical assistance in the English translation. Also, thanks to the editor and anonymous reviewers for their valuable corrections, and to all the authors cited in this article, or researching in the mentioned fields, for their appreciated contributions.

\section{References}

Acevedo, B. P., Aron, A., Fisher, H. E., \& Brown, L. L. (2012). Neural Correlates of Long-Term Intense Romantic Love. Social Cognitive and Affective Neuroscience, 7, 145-159. http://dx.doi.org/10.1093/scan/nsq092

Alea, N., \& Vick, S. C. (2010). The First Sight of Love: Relationship-Defining Memories and Marital Satisfaction across Adulthood. Memory, 18, 730-742. http://dx.doi.org/10.1080/09658211.2010.506443

Aragona, B. J., Liu, Y., Curtis, J. T., Stephan, F. K., \& Wang, Z. (2003). A Critical Role for Dopamine in Partner-Preference Formation in Male Prairie Voles. The Journal of Neuroscience, 23, 3483-3490.

Aragona, B. J., Liu, Y., Yu, Y. J., Curtis, J. T., Detwiler, J. M., Inser, T. R., \& Wang, Z. (2006). Nucleus Accumbens Dopamine Differentially Mediates the Formation and Maintenance of Monogamous Pair Bonds. Nature Neuroscience, 9, 7-8. http://dx.doi.org/10.1038/nn1613

Aron, A., Fisher, H., Mashek, D. J., Strong, G., Li, H., \& Brown, L. L. (2005). Reward, Motivation and Emotion Systems Associated with Early-Stage Intense Romantic Love. Journal of Neurophysiology, 94, 327-337.

http://dx.doi.org/10.1152/jn.00838.2004 
Bäckman, O., \& Nilsson, A. (2011). Pathways to Social Exclusion: A Life-Course Study. European Sociological Review, 27, 107-123.

Bäckman, O., Estrada, F., Nilsson, A., \& Shannon, D. (2014). The Life Course of Young Male and Female Offenders. Stability or Change between Different Birth Cohorts? British Journal Criminology, 54, 393-410.

http://dx.doi.org/10.1093/bjc/azu007

Bartels, A., \& Seki, S. (2000). The Neural Basis of Romantic Love. Neuroreport, 11, 3829-3834. http://dx.doi.org/10.1097/00001756-200011270-00046

Bartels, A., \& Seki, S. (2004). The Neural Correlates of Maternal and Romantic Love. Neuroimage, 21, 1155-1166. http://dx.doi.org/10.1016/j.neuroimage.2003.11.003

Bauer, N. S., Gilbert, A. L., Carroll, A. E., \& Down, S. M. (2013). Association of Early Exposure to Intímate Partner Violence and Parental Depression with Subsequent Mental Health Outcomes. JAMA Pediatrics, 167, 341-347. http://dx.doi.org/10.1001/jamapediatrics.2013.780

Bermúdez de Castro, J. M., Martinón-Torres, M., Prado, L., Gómez-Robles, A., Rosell, J., López-Polín, L., Arsuaga, J. L., \& Carbonell, E. (2010). New Immature Hominin Fossil from European Lower Pleistocen Shown the Earliest Evidence of a Modern Human Dental Development Pattern. Proceedings of the National Academy of Sciences of the United States of America, 107, 11739-11744. http://dx.doi.org/10.1073/pnas.1006772107

Bokma, F., van den Brink, V., \& Stadler, T. (2012). Unexpectedly Many Extinct Hominins. Evolution, 66, $2969-2974$. http://dx.doi.org/10.1111/j.1558-5646.2012.01660.x

Bowers, J. M., Perez-Pouchoulen, M., Edwards, N. S., \& McCarthy, M. M. (2013). Foxp2 Mediates Sex Differences in Ultrasonic Vocalization by Rat Pups and Directs Order of Maternal Retrieval. The Journal of Neuroscience, 33, 3276-3283. http://dx.doi.org/10.1523/JNEUROSCI.0425-12.2013

Bremmer, J. D., Narayan, M., Staib, L. H., Southwick, S. M., McGlashan, T., \& Charney, D. S. (1999). Neural Correlates of Memories of Childhood Sexual Abuse in Women with and without Posttraumatic Stress Disorder. The American Journal of Psychiatry, 156, 1787-1795.

Bremner, J. D., Vythilingam, M., Vermetten, E., Southwick, S. M., McGlashan, T., Nazeer, A., Khan, S., Vaccarino, L. V., Soufer, R., Garg, P. K., Ng, C. K., Staib, L. H., Duncan, J. S., \& Charney, D. S. (2003). MRI and PET Study of Deficits in Hippocampal Structure and Function in Women with Childhood Sexual Abuse and Posttraumatic Stress Disorder. The American Journal of Psychiatry, 160, 924-932.

Burunat, E. (2014). Amor y origen de la Humanidad. Madrid: Bubok Publishing.

Cacioppo, S., Bianchi-Demicheli, F., Frum, C., Pfaus, J. G., \& Lewis, J. W. (2012). The Common Neural Bases between Sexual Desire and Love: A Multilevel Kernel Density fMRI Analysis. The Journal of Sexual Medicine, 9, 1048-1054. http://dx.doi.org/10.1111/j.1743-6109.2012.02651.x

Carey, I. M., Shah, S. M., DeWilde, S., Harris, T., Victor, C. R., \& Cook, D. G. (2014). Increased Risk of Acute Cardiovascular Events after Partner Bereavement. Journal of the American Medical Association Internal Medicine, 174, 598-605. http://dx.doi.org/10.1001/jamainternmed.2013.14558

Casey, B. J., Giedd, J. N., \& Thomas, K. M. (2003). Structure and Functional Brain Development and Its Relation to Cognitive Development. Biological Psychology, 54, 241-257. http://dx.doi.org/10.1016/S0301-0511(00)00058-2

Chan, K. Q., Tong, E. M., Tan, D. H., \& Koh, A. H. (2013). What Do Love and Jealousy Taste Like? Emotion, 13, 11421149. http://dx.doi.org/10.1037/a0033758

Cheng, Y., Chen, C., Lin, C. P., Chou, K. H., \& Decety, J. (2010). Love Hurts: An fMRI Study. Neuroimage, 51, $923-929$. http://dx.doi.org/10.1016/j.neuroimage.2010.02.047

Ciaramelli, E., Bernardi, F., \& Moscovitch, M. (2013). Individualized Theory of Mind (iTOM): When Memory Modulates Empathy. Frontiers in Psychology, 4, 4. http://dx.doi.org/10.3389/fpsyg.2013.00004

Costa, R. M., \& Brody, S. (2007). Women’s Relationship Quality Is Associated with Specifically Penile-Vaginal Intercourse Orgasm and Frequency. Journal of Sex and Marital Therapy, 33, 319-327. http://dx.doi.org/10.1080/00926230701385548

Costa, R. M., Miller, G. F., \& Brody, B. (2012). Women Who Prefer Longer Penises Are More Likely to Have Vaginal Orgasms (but Not Clitoral Orgasms): Implications for an Evolutionary Theory of Vaginal Orgasm. Journal of Sexual Medicine, 9, 2079-3088. http://dx.doi.org/10.1111/j.1743-6109.2012.02917.x

Courtiol, A., Pettay, J. E., Jokela, M, Rotkirch, A., \& Lummaa, V. (2012). Natural and Sexual Selection in a Monogamous Historical Human Population. Proceedings of the National Academy of Sciences of the United States of America, 109, 8044-8049. http://dx.doi.org/10.1073/pnas.1118174109

Crews, D. E. (2003). Human Senescence: Evolutionary and Biocultural Perspectives. New York: Cambridge University Press. http://dx.doi.org/10.1017/CBO9780511542350 
Darwin, C. (1871). The Descent of Man, and Selection in Relation to Sex. London: John Murray. http://dx.doi.org/10.1037/12293-000

Darwin, C. (1872). The Expression of the Emotions in Man and Animals. London: John Murray. http://dx.doi.org/10.1037/10001-000

Davila-Ross, M., Owren, M. J., \& Zimmermann, E. (2009). Reconstructing the Evolution of Laughter in Great Apes and Humans. Current Biology, 19, 1106-1111. http://dx.doi.org/10.1016/j.cub.2009.05.028

Dunbar, R. I. (2012). The Social Brain Meets Neuroimaging. Trends in Cognitive Sciences, 16, 101-102. http://dx.doi.org/10.1016/j.tics.2011.11.013

Dunsworth, H. M., Warrener, A. G., Deacon, T., Ellison, P. T., \& Pontzer, H. (2012). Metabolic Hypothesis for Human Altriciality. Proceedings of the National Academy of Sciences of the United States of America, 109, 15212-15216. http://dx.doi.org/10.1073/pnas.1205282109

Ebstein, R. P., Israel, S., Chew, S. H., Zohng, S., \& Knafo, A. (2010). Genetics of Human Social Behavior. Neuron, 65, 831844. http://dx.doi.org/10.1016/j.neuron.2010.02.020

Edmiston, E. E., Wang, F., Mazure, C. M., Guiney, J., Sinha, R., Mayes, L. C., \& Blumberg, H. P. (2011). CorticostriatalLimbic Gray Matter Morphology in Adolescents with Self-Reported Exposure to Childhood Maltreatment. Archives of Pediatrics and Adolescent Medicine, 165, 1069-1077. http://dx.doi.org/10.1001/archpediatrics.2011.565

Ekman, P. (2009). Darwin's Contribution to Our Understanding of Emotional Expressions. Philosophical Transactions of the Royal Society B: Biological Sciences, 364, 3449-3451. http://dx.doi.org/10.1098/rstb.2009.0189

Emery-Thompson, M., Jones, J. H., Pusey, A. E., Brewer-Marsden, S., Goodall, J., Marsden, E., Matsuzawa, T., Nishida, T., Reynolds, V., Sugiyama, Y., \& Wrangham, R. W. (2007). Aging and Fertility Patterns in Wild Chimpanzees Provide Insights into the Evolution of Menopause. Current Biology, 17, 2150-2156. http://dx.doi.org/10.1016/j.cub.2007.11.033

Enard, W. (2011). FOXP2 and the Role of Cortico-Basal Ganglia Circuits in Speech and Language Evolution. Current Opinion in Neurobiology, 21, 425-424. http://dx.doi.org/10.1016/j.conb.2011.04.008

Erikson, M., Marschik, P. B., Tulviste, T., Almgren, M., Pereira, M. P., Wehberg, S., Marjanovič-Umek, L., Gayraud, F., Kovacevic, M., \& Gallego, C. (2012). Differences between Girls and Boys in Emerging Language Skills: Evidence from 10 Language Communities. British Journal of Developmental Psychology, 30, 326-346. http://dx.doi.org/10.1111/j.2044-835X.2011.02042.x

Espinosa, J. S., \& Stryker, M. P. (2012). Development and Plasticity of the Primary Visual Cortex. Neuron, 75, $230-249$. http://dx.doi.org/10.1016/j.neuron.2012.06.009

Fischer, H. E., Aron, A., \& Brown, L. L. (2006). Romantic Love: A Mammalian Brain System for Mate Choice. Philosophical Transactions of the Royal Society B: Biological Sciences, 361, 2173-2186. http://dx.doi.org/10.1098/rstb.2006.1938

Fischer, H. E., Aron, A., Mashek, D., Li, H., Strong, G., \& Brown, L. L. (2002). Review: The Neural Mechanisms of Mate Choice: A Hypothesis. Neuroendocrinology Letters, 23, 92-97.

Fisher, H. E. (1998). Lust, Attraction, and Attachment in Mammalian Reproduction. Human Nature, 9, $23-52$. http://dx.doi.org/10.1007/s12110-998-1010-5

Fisher, H. E., Brown, L. L., Aron, A., Strong, G., \& Mashek, D. (2010). Reward, Addiction, and Emotion Regulation Systems Associated with Rejection in Love. Journal of Neurophisiology, 104, 51-60. http://dx.doi.org/10.1152/jn.00784.2009

Fisher, H.E. (2004). Why We Love: The Nature and Chemistry of Romantic Love. New York: Henry Holt.

Fonseca-Azevedo, K., \& Herculano-Houzel, S. (2012). Metabolic Constraint Imposes Tradeoff between Body Size and Number of Brain Neurons in Human Evolution. Proceedings of the National Academy of Sciences of the United States of America, 109, 18571-18576. http://dx.doi.org/10.1073/pnas.1206390109

Freidline, S. E., Gunz, P., Jankoić, I., Harvati, K, \& Hublin, J. J. (2012). A Comprehensive Morphometric Analysis of the Frontal and Zygomatic Bone of the Zuttiyeh Fossil from Israel. Journal of Human Evolution, 62, 225-241 http://dx.doi.org/10.1016/j.jhevol.2011.11.005

Gallese, V., Fadiga, L., Fogassi, L., \& Rizzolatti, G. (1996). Action Recognition in the Premotor Cortex. Brain, 119, 593609.

Gallese, V., Fadiga, L., Fogassi, L., \& Rizzolatti, G. (2002). Action Representation in the Inferior Parietal Lobule. Common Mechanisms in Perception and Action, 19, 334-355.

Gallese, V., Keysers, C., \& Rizzolatti, G. A. (2004). A Unifying View of the Basis of Social Cognition. Trends in Cognitive Sciences, 8, 396-403. http://dx.doi.org/10.1016/j.tics.2004.07.002

Gannon, P. J., Holloway, R. L., Broadfield, D. C., \& Braun, A. R. (1998). Asymmetry of Chimpanzee Planum Temporal: Humanlike Pattern of Wernicke’s Brain Language Area Homolog. Science, 279, 220-222. 
http://dx.doi.org/10.1126/science.279.5348.220

Gavrilet, S. (2012). Human Origins and the Transition from Promiscuity to Pair-Bonding. Proceedings of the National Academy of Sciences of the United States of America, 109, 9923-9928. http://dx.doi.org/10.1073/pnas.1200717109

Goldfield, B. A., \& Reznick, J. S. (1990). Early Lexical Acquisition: Rate, Content, and the Vocabulary Spurt. Journal of Child Language, 17, 171-183. http://dx.doi.org/10.1017/S0305000900013167

Gracia, A., Arsuaga, J. L., Martínez, I., Lorenzo, C., Carretero, J. M., de Castro, J. M. B., \& Carbonell, E. (2009). Craniosynostosis in the Middle Pleistocene Human Cranium 14 from the Sima de los Huesos, Atapuerca, Spain. Proceedings of the National Academy of Sciences of the United States of America, 106, 6573-6578. http://dx.doi.org/10.1073/pnas.0900965106

Gray, P. B. (2013). Evolution and Human Sexuality. American Journal of Physical Anthropology, 152, 94-118. http://dx.doi.org/10.1002/ajpa.22394

Gueguen, N. (2007). Women’s Bust Size and Men Courtship Solicitation. Body Image, 4, 386-390. http://dx.doi.org/10.1016/j.bodyim.2007.06.006

Guillermo, C. J., Manlove, H. A., Gray, P. B., Zava, D. T., \& Marrs, C. R. (2010). Female Social and Sexual Interest across the Menstrual Cycle: The Roles of Pain, Sleep and Hormones. BMC Women Health, 10, 19. http://dx.doi.org/10.1186/1472-6874-10-19

Haeusler, M., Schiess, R., \& Boeni, T. (2013). Evidence for Juvenile Disc Herniation in a Homo Erectus Boy Skeleton. Spine, 38, E123-128. http://dx.doi.org/10.1097/BRS.0b013e31827cd245

Harasty, J., Double, K. L., Halliday, G. M., Krill, J. J., \& McRitchie, D. A. (1997). Language-Associated Cortical Regions Are Proportionally Larger in the Female Brain. Archives of Neurology, 54, 171-176. http://dx.doi.org/10.1001/archneur.1997.00550140045011

Harrison, B. J., Soriano-Mas, C., Pujol, J., Ortiz, H., López-Solá, M., Hernández-Ribas, R., Deus, J., Alonso, P., Yücel, M., Pantelis, C., Menchon, J. M., \& Cardoner, N. (2009). Altered Corticostriatal Funcional Connectivity in Obsessive-Compulsive Disorder. Archives of General Psychiatry, 66, 1189-1200. http://dx.doi.org/10.1001/archgenpsychiatry.2009.152

Hart, C. L., Hole, D. J., Lawlor, D. A., Smith, G. D., \& Lever, T. F. (2007). Effect of Conjugal Bereavement on Mortality of the Bereaved Spouse in Participants of the Renfrew/Paisley Study. Journal of Epidemiology and Community Health, 61, 455-460. http://dx.doi.org/10.1136/jech.2006.052043

Hawkes, K., \& Coxworth, J. E. (2013). Grandmothers and the Evolution of Human Longevity: A Review of Findings and Future Directions. Evolutionary Anthropology: Issues, News, and Reviews, 22, 294-302. http://dx.doi.org/10.1002/evan.21382

Hawkes, K., \& Smith, K. R. (2009). Brief Communication: Evaluating Grandmother Effects. American Journal of Physical Anthropology, 140, 173-176. http://dx.doi.org/10.1002/ajpa.21061

Herndon, J. G., Paredes, J., Wilson, M. E., Bloomsmith, M. A., Chennareddi, L., \& Walker, M. L. (2012). Menopause Occurs Late in Life in the Captive Chimpanzee (Pan troglodytes). Age, 34, 1145-1156. http://dx.doi.org/10.1007/s11357-011-9351-0

Höglund, J., Jern, P., Sandnabba, N. K., \& Santtila, P. (2014). Finnish Women and Men Who Self-Report No Sexual Attraction in the Past 12 Months: Prevalence, Relationship Status, and Sexual Behavior History. Archives of Sexual Behavior, Published Online. http://dx.doi.org/10.1007/s10508-013-0240-8

Hublin, J. J. (2009). The Prehistory of Compassion. Proceedings of the National Academy of Sciences of the United States of America, 106, 6429-6430. http://dx.doi.org/10.1073/pnas.0902614106

Iacoboni, M., Lieberman, M. D., Knowlton, B. J., Molnar-Szakacs, I., Moritz, M., Throop, C. J., \& Fiske, A. P. (2004). Watching Social Interactions Produces Dorsomedial Prefrontal and Medial Parietal BOLD fMRI Signal Increases Compared to a Resting Baseline. Neuroimage, 21, 1167-1173. http://dx.doi.org/10.1016/j.neuroimage.2003.11.013

Inta, D., Meyer-Lindenberg, A., \& Gass, P. (2011). Alterations in Postnatal Neurogenesis and Dopamine Dysregulation in Schizophrenia: A Hypothesis. Schizophrenia Bulletin, 37, 674-680. http://dx.doi.org/10.1093/schbul/sbq134

Jablonka, E., Ginsburg, S., \& Dor, D. (2012). The Co-Evolution of Language and Emotions. Philosophical Transactions of the Royal Society B: Biological Sciences, 367, 2152-2159. http://dx.doi.org/10.1098/rstb.2012.0117

Johansson, S. (2013). The Talking Neanderthals: What Do Fossils, Genetics, and Archeology Say? Biolinguistic, 7, 35-74.

Kay, R. F., Cartmill, M., \& Balow, M. (1998). The Hypoglossal Canal and the Origin of Human Vocal Behavior. Proceedings of the National Academy of Sciences of the United States of America, 95, 5417-5419. http://dx.doi.org/10.1073/pnas.95.9.5417

Kim, W., Kim, S., Jeong, J., Lee, K. U., Ahn, K. J., Chung, Y. A., Hong, K. Y., \& Chae, J. H. (2009). Temporal Changes in Functional Magnetic Resonance Imaging Activation of Heterosexual Couples for Visual Stimuli of Loved Partners. Psychiatry Investigation, 6, 19-25. http://dx.doi.org/10.4306/pi.2009.6.1.19 
Klein, D., Mok, K., Chen, J. K., \& Watkins, K. E. (2013). Age of Language Learning Shapes Brain Structure: A Cortical Thickness Study of Bilingual and Monolingual Individuals. Brain and Language, 131, 20-24. http://dx.doi.org/10.1016/j.bandl.2013.05.014

Koch, K., Pauly, K., Kellermann, T., Seiferth, N. Y., Reske, M., Backes, V., Stöcker, T., Shah, N. J., Amunts, K., Kircher, T, Schneider, F., \& Habel, U. (2007). Gender Differences in the Cognitive Control of Emotion: An fMRI Study. Neuropsychologia, 45, 2744-2753. http://dx.doi.org/10.1016/j.neuropsychologia.2007.04.012

Kolb, B., \& Whishaw, I. Q. (1998). Brain Plasticity and Behavior. Annual Review of Psychology, 49, 43-64. http://dx.doi.org/10.1146/annurev.psych.49.1.43

Kramer, R. S., Jones, A. L., \& Ward, R. (2012). A Lack of Sexual Dimorphism in Width-to-Height Ratio in White European Faces Using 2D Photographs, 3D Scans, and Anthropometry. PLoS ONE, 7, e42705. http://dx.doi.org/10.1371/journal.pone.0042705

Kwon, M., Lee, J. Y., Won, W. Y., Park, J. W., Min, J. A., Hahn, C., Gu, X., Choi, J. H., \& Kim, D. J. (2013). Development and Validation of a Smartphone Addiction Scale (SAS). PLOS ONE, 8, e56936. http://dx.doi.org/10.1371/journal.pone.0056936

Lai, C. S., Fisher, S. E., Hurst, J. A., Vargha-Khadem, F., \& Monaco, A. P. (2001). A Forkhead-Domain Gene Is Mutated in a Severe Speech and Language Disorder. Nature, 413, 519-523. http://dx.doi.org/10.1038/35097076

Langeslaq, S. J., van der Veen, F. M., \& Röder, C. H. (2014). Attention Modulates the Dorsal Striatum Response to Love Stimuli. Human Brain Mapping, 35, 503-512. http://dx.doi.org/10.1002/hbm.22197

Madrigal, L., \& Meléndez-Obando, M. (2008). Grandmothers’ Longevity Negatively Affects Daughters’ Fertility. American Journal of Physical Anthropology, 136, 223-229. http://dx.doi.org/10.1002/ajpa.20798

Maricic, T., Günther, V., Georgiev, O., Gehre, S., Ćurlin, M, Schreiweis, C., Naumann, R., Burbano, H. A., Meyer, M., Lalueza-Fox, C. et al. (2013). A Recent Evolutionary Change Affects a Regulatory Element in the Human FOXP2 Gene. Molecular Biology and Evolution, 30, 844-852. http://dx.doi.org/10.1093/molbev/mss271

Márquez, C., Poirier, G. L., Cordero, M. I., Larsen, M. H., Groner, A., Marquis, J., Magistretti, J., Trono, D., \& Sandi, C. (2013). Peripuberty Stress Leads to Abnormal Aggression, Altered Amygdala and Orbitofrontal Reactivity and Increased Prefrontal MAOA Gene Expression. Translational Psychiatry, 3, e216. http://dx.doi.org/10.1038/tp.2012.144

Mascie-Taylor, C. G. N., \& Boyce, A. J. (Eds.) (2009). Human Mating Patterns. Society for the Study of Human Biology, Symposium Series, Cambridge: Cambridge University Press.

Mathew, S. J., Mao, X., Coplan, J. D., Smith, E. L. P., Sackeim, H. A., Gorman, J. M., \& Shungu, D. C. (2004). Dorsolateral Prefrontal Cortical Pathology in Generalized Anxiety Disorder: A Proton Magnetic Resonance Spectroscopic Imaging Study. American Journal of Psychiatry, 161, 1119-1121. http://dx.doi.org/10.1176/appi.ajp.161.6.1119

Maul, A. (2007). An Evolutionary Interpretation of the Significance of Physical Pain Experienced by Human Females: Defloration and Childbirth Pains. Medical Hypotheses, 69, 403-409. http://dx.doi.org/10.1016/j.mehy.2007.01.005

Mautz, B. S., Wong, B. B., Peters, R. A., \& Jennions, M. D. (2013). Penis Size Interacts with Body Shape and Height to Influence Male Attractiveness. Proceedings of the National Academy of Sciences of the United States of America, 110, 69256930. http://dx.doi.org/10.1073/pnas.1219361110

McGregor, I. S., \& Bowen, M. T. (2012). Breaking the Loop: Oxytocin as a Potential Treatment for Drug Addiction. Hormones and Behavior, 61, 331-339. http://dx.doi.org/10.1016/j.yhbeh.2011.12.001

Meyer, G., Gonzalez-Hernandez, T., Carrillo-Padilla, F., \& Ferres-Torres, R. (1998). Aggregations of Granule Cells in the Basal Forebrain (Islands of Calleja): Golgi and Cytoarchitectonic Study in Different Mammals, Including Man. Journal of Comparative Neurology, 284, 405-428. http://dx.doi.org/10.1002/cne.902840308

Miller, G. F. (2007). Sexual Selection for Moral Virtues. The Quarterly Review of Biology, 82, 97-125. http://dx.doi.org/10.1086/517857

Min, K. J., Lee, C. K., \& Park, H. N. (2012). The Lifespan of Korean Eunuchs. Current Biology, 22, R792-R793. http://dx.doi.org/10.1016/j.cub.2012.06.036

Mitchell, H., \& Aamodt, M. G. (2005). The Incidence of Child Abuse in Serial Killers. Journal of Police and Criminal Psychology, 20, 40-47. http://dx.doi.org/10.1007/BF02806705

Modroño, C. (2012). Theory of Mind and Mirror Neurons in Complex Environments: An fMRI Study. PH.D. Thesis, La Laguna: University of La Laguna.

Modroño, C., Navarrete, G., Rodríguez-Hernández, A., \& González-Mora, J. L. (2013). Activation of the Human Mirror Neuron System during the Observation of the Manipulation of Virtual Tools in the Absence of a Visible Effector Limb. Neuroscience Letters, 555, 220-224. http://dx.doi.org/10.1016/j.neulet.2013.09.044

Moorad, J. (2013). Multi-Level Sexual Selection: Individual and Family Level Selection for Mating Success in a Historical Human Population. Evolution, 67, 1635-1648. http://dx.doi.org/10.1111/evo.12050 
Moorman, S., Gobes, S. M., Kuijpers, M., Kerkhofs, A., Zandbergen, M. A., \& Bolhuis, J. J. (2012). Human-Like Brain Hemispheric Dominance in Birdsong Learning. Proceedings of the National Academy of Sciences of the United States of America, 109, 12782-12787. http://dx.doi.org/10.1073/pnas.1207207109

Nelson, E., Rolian, C., Cashmore, L., \& Shultz, S. (2011). Digit Ratios Predict Polyginy in Early Apes, Ardipithecus, Neanderthals and Early Modern Humans but Not in Australopithecus. Proceedings of the Royal Society B: Biological Sciences, 278, 1556-1563. http://dx.doi.org/10.1098/rspb.2010.1740

Neumann, I. D. (2008). Brain Oxytocin: A Key Regulator of Emotional and Social Behaviours in Both Females and Males. Journal of Endocrinology, 20, 858-865.

Ohoka, H., Koide, T., Goto, S., Murase, S., Kanai, A., Masuda, T., Aleksic, B., Ishikawa, N., Furumura, K., \& Ozaki, N. (2014). Effects of Maternal Depressive Symptomatology during Pregnancy and the Postpartum Period on Infant-Mother Attachment. Psychiatry and Clinical Neurosciences, Early View. http://dx.doi.org/10.1111/pcn.12171

Olausson, H., Lamarre, Y., Backlund, H. et al. (2002). Unmyelinated Tactile Afferents Signal Touch and Project to Insular Cortex. Nature Neuroscience, 5, 900-904. http://dx.doi.org/10.1038/nn896

Ortique, S., Bianchi-Demicheli, F., Patel., N., Frum, C., \& Lewis, J. W. (2010). Neuroimaging of Love: fMRI Meta-Analysis Evidencie toward New Perspectives in Sexual Medicine. The Journal of Sexual Medicine, 7, 3541-3552. http://dx.doi.org/10.1111/j.1743-6109.2010.01999.x

Ortique, S., Grafton, S. T., \& Bianchi-Demiceli, F. (2007). Correlation between Insula Activation and Self-Reported Quality of Orgasm in Women. Neuroimage, 37, 551-560. http://dx.doi.org/10.1016/j.neuroimage.2007.05.026

Overmann, K. A., \& Coolidge, F. L. (2013). Human Species and Mating Systems: Neandertal-Homo Sapiens Reproductive Isolation and the Archaeological and Fossil Records. Journal of Anthropological Sciences, 91, 91-110.

Pearce, E., Stringer, C., \& Dunbar, R. (2013). New Insights into Differences in Brain Organization between Neanderthals and Anatomically Modern Humans. Proceedings of the Royal Society B: Biological Sciences, 280, Article ID: 20130168. http://dx.doi.org/10.1098/rspb.2013.0168

Pedersen, C. A. (2014). Schizophrenia and Alcohol Dependence: Diverse Clinical Effects of Oxytocin and Their Evolutionary Origins. Brain Research, Available Online. http://dx.doi.org/10.1016/j.brainres.2014.01.050

Perlman, L. V., Fergusson, S., Bergum, K. L., Isenberg, E. L., \& Hammarsten, J. F. (1971). Precipitation of Congestive Heart Failure: Social and Emotional Factors. Annals of Internal Medicine, 75, 1-7. http://dx.doi.org/10.7326/0003-4819-75-1-1

Playcan, J. M. (2012). Sexual Size Dimorphism, Canine Dimorphism, and Male-Male Competition in Primates. Human Nature, 23, 45-67. http://dx.doi.org/10.1007/s12110-012-9130-3

Porges, E. C., \& Decety, J. (2013). Violence as a Source of Pleasure or Displeasure Is Associated with Specific Functional Connectivity with the Nucleus Accumbens. Frontiers in Human Neuroscience, 7, 447. http://dx.doi.org/10.3389/fnhum.2013.00447

Powers, K. E., Wagner, D. D., Norris, C. J., \& Heatherton, T. F. (2011). Socially Excluded Individuals Fail to Recruit Medial Prefrontal Cortex for Negative Social Scenes. Social Cognitive and Affective Neuroscience, 8, 151-157. http://dx.doi.org/10.1093/scan/nsr079

Reynaud, M., Karifa, L., Biecha, L., \& Benyamina, A. (2010). Is Love Passion an Addictive Disorder? The American Journal of Drug and Alcohol Abuse, 36, 261-267. http://dx.doi.org/10.3109/00952990.2010.495183

Robson, S. L., \& Wood, B. (2008). Hominin Life Story: Reconstruction and Evolution. Jounal of Anatomy, 212, 394-425. http://dx.doi.org/10.1111/j.1469-7580.2008.00867.x

Romano, M., Osborne, L. A., Truzoli, R., \& Reed, P. (2013). Differential Psychological Impact of Internet Exposure on Internet Addicts. PLOS ONE, 8, e55162. http://dx.doi.org/10.1371/journal.pone.0055162

Rosenberg, J. G., Herbenick, D., Novak, D. S., \& Reece, M. (2014). What's Love Got to Do with It? Examination of Emotional Perception and Sexual Behaviors among Gay and Bisexual Men in the United States. Archives of Sexual Behavior, 43, 119-128. http://dx.doi.org/10.1007/s10508-013-0223-9

Rozzi, R., \& Bermúdez, J.M. (2004). Surprisingly Rapid Growth in Neanderthals. Nature, 428, 936-939. http://dx.doi.org/10.1038/nature02428

Sagarin, B. J., Martin, A. L., Coutinho, S. A., Edlund, J. E., Patel, L., Skowronsky, J. J., \& Zengel, B. (2012). Sex Differences in Jealousy: A Meta-Analytic Examination. Evolution and Human Behavior, 33, 595-614.

Sale, P., \& Franceschini, M. (2012). Action Observation and Mirror Neuron Network: A Tool for Motor Stroke Rehabilitation. European Journal of Physical and Rehabilitation Medicine, 48, 313-318.

Sampson, R. J., \& Wikström, P. O. (2008). The Social Order of Violence in Chicago and Stockholm Neighborhoods: A Comparative Inquiry. In S. N. Kalyvas, I. Shapiro, \& T. Masoud (Eds.), Order, Conflict and Violence (pp. 97-119). Cambridge: Cambridge University Press.

Scheele, D., Wille, A., Kendrick, K. M., Stoffel-Wagner, B., Becker, B., Güntürkün, O., Maier, W., \& Hurlemann, R. (2013). 
Oxytocin Enhances Brain Reward System Responses in Men Viewing the Face of Their Female Partner. Proceedings of the National Academy of Sciences of the United States of America, 110, 20308-20313.

http://dx.doi.org/10.1073/pnas.1314190110

Schneiderman, I., Kanat-Maymon, Y., Ebstein, R. F., \& Feldman, R. (2013). Cumulative Risk on the Oxytocin Receptor Gene (OXTR) Underpins Empathic Communication Difficulties at the First Stage of Romantic Love. Social Cognitive and Affective Neuroscience, Published Online. http://dx.doi.org/10.1093/scan/nst142

Schwartz, J. H., \& Tattersall, I. (2010). Fossil Evidence for the Origin of Homo Sapiens. American Journal of Physical Anthropology, 143, 94-121.http://dx.doi.org/10.1002/ajpa.21443

Seifarth, J. E., McGowan, C. L., \& Milne, K. J. (2012). Sex and Life Expectancy. Gender Medicine, 9, 390-401. http://dx.doi.org/10.1016/j.genm.2012.10.001

Shapiro, L. A., Ng, K., Zhou, Q. Y., \& Ribak, C. E. (2009). Subventricular Zone-Derived Newly Generated Neurons Populate Several Olfactory and Limbic Forebrain Regions. Epilepsy and Behavior, 14, 74-80. http://dx.doi.org/10.1016/j.yebeh.2008.09.011

Singer, T., Seymour, B., O’Doherty, J., Kaube, H., Dolan, R. J., \& Frith, C. D. (2004). Empathy for Pain Involves the Affective but Not Sensory Components of Pain. Science, 303, 1157-1162.

Singh, R. R., Cuffe, J. S., \& Moritz, K. M. (2012). Short- and long-Term Effects of Exposure to Natural and Synthetic Glucocorticoids during Development. Clinical and Experimental Pharmacology and Physiology, 39, 979-989. http://dx.doi.org/10.1111/1440-1681.12009

Smith, T. M., Machanda, Z., Bernanrd, A. B., Donovoan, R. M., Papakyrikos, A. M., Muller, M. N., \& Wranghan, R. (2013). First Molar Eruption, Weaning, and Life History in Living Wild Chimpanzees Proceedings of the National Academy of Sciences of the United States of America, 110, 2787-2791. http://dx.doi.org/10.1073/pnas.1218746110

Smith, T. M., Tafforeau, P., Reid, D. J., Pouech, J., Lazzari, Y., Zermeno, P., Guateli-Steinberg, D., Olejnizack, A. J., Hoffman, A., Radovčić, J., Makaremi, M., Toussaint, M., Stringer, C., \& Hublin, J. J. (2010). Dental Evidence for Ontogenetic Differences between Modern Humans and Neanderthals. Proceedings of the National Academy of Sciences of the United States of America, 107, 20923-20928. http://dx.doi.org/10.1073/pnas.1010906107

Stancak, A., \& Fallon, N. (2013). Emotional Modulation of Experimental Pain: A Source Imaging Study of Laser Evoked Potentials. Frontiers in Human Neuroscience, 7, 552. http://dx.doi.org/10.3389/fnhum.2013.00552

Sternberg, R. J. (2004). A Triangular Theory of Love. In H. T. Reiss, \& C. E. Rusbult (Eds.), Close Relationships (Part 4). New York: Psychology Press.

Stevens, J. R. (2002). Schizophrenia: Reproductive Hormones and the Brain. American Journal of Psychiatry, 159, $713-719$. http://dx.doi.org/10.1176/appi.ajp.159.5.713

Sutou, S. (2012). Hairless Mutation: A Driving Force of Humanization from a Human-Ape Common Ancestor by Enforcing Upright Walking While Holding a Baby with Both Hands. Gene to Cells, 17, 264-272.

http://dx.doi.org/10.1111/j.1365-2443.2012.01592.x

Tamir, D. I., and Mitchell, J. P. (2012). Disclosing Information about the Self Is Intrinsically Rewarding. Proceedings of the National Academy of Sciences of the United States of America, 109, 8038-8043. http://dx.doi.org/10.1073/pnas.1202129109

Tattersall, I., \& Matternes, J. H. (2003). New Look at Human Evolution. Scientific American, 13, 20-27. http://www.zo.utexas.edu/courses/kalthoff/bio301c/readings/04Tattersall.pdf

Toivonen, R., Kivelä, M., Saramäky, J., Viinikainen, M., Vanhatalo, M., \& Sams, M. (2012). Networks of Emotion Concepts. PLOS ONE, 7, e28883.

Tosevski, J., \& Tosevski, D. (2006). Concealed Female External Genitals: Possible Morpho-Psychological Clue to Unique Emotional and Cognitive Evolutionary Matrix of Man. Medical Science Monitor, 12, HY11-HY19.

Trinkaus, E. (1985). Pathology and the Posture of the La Chapelle-aux-Saints Neanderthal. American Journal of Physical Anthropology, 67, 19-41. http://dx.doi.org/10.1002/ajpa.1330670105

Vitzthum, V. J. (2009). The Ecology and Evolutionary Endocrinology of Reproduction in the Human Female. American Journal of Physical Anthropologists, 140, 95-136. http://dx.doi.org/10.1002/ajpa.21195

Vronsky, P. (2004). Serial Killers: The Method and Madness of Monsters. New York: Penguin Books.

Wan, C. Y., Demaine, K., Zipse, L., Norton, A., \& Schlag, G. (2010). From Music Making to Speaking: Engaging the Mirror Neuron System in Autism. Brain Research Bulletin, 82, 161-168. http://dx.doi.org/10.1016/j.brainresbull.2010.04.010

Weber, S., \& Lehmann, E. (2005). Abnormal Responses to the Loss of a Loved One. MMW Fortschritte der Medizin, 147, 36-40.

Wetherill, R. R., Jagannathan, K., Shin, J., \& Franklin, T. R. (2014). Sex Differences in Resting State Neural Networks of 
Nicotine-Dependent Cigarette Smoking. Addictive Behavior, 39, 789-792. http://dx.doi.org/10.1016/j.addbeh.2014.01.006.

Wingard, D. L. (1982). The Sex Differential in Mortality Rates: Demographic and Behavioral Factors. American Journal of Epidemiology, 115, 205-216.

Winternitz, J. C., Minchey, S. G., Garamszegi, L. Z., Huang, S., Stephens, P. R., \& Altizer, S. (2013). Sexual Selection Explains More Functional Variation in the Mammalian Major Histocompatibility Complex than Parasitism. Proceedings of the Royal Society B: Biological Sciences, 280, Article ID: 20131605. http://dx.doi.org/10.1098/rspb.2013.1605

Wong, N., Beidel, D. C., Sarver, D. E., \& Sims, V. (2012). Facial Emotion Recognition in Children with High Functioning Autism and Children with Social Phobia. Child Psychiatry and Human Development, 43, 775-794. http://dx.doi.org/10.1007/s10578-012-0296-z

World Health Organization (2013). World Health Statistics, Part III.

Xu, X., Aron, A., Brown, L., Cao, G., Feng, T., \& Weng, X. (2011). Reward and Motivation Systems: A Brain Mapping Study of Early-Stage Intense Romantic Love in Chinese Participants. Human Brain Mapping, 32, 249-257. http://dx.doi.org/10.1002/hbm.21017

Yang, C. (2013). Ontogeny and Phylogeny of Language. Proceedings of the National Academy of Sciences of the United States of America, 110, 6324-6327. http://dx.doi.org/10.1073/pnas.1216803110 